\title{
Temperature Effect on Seed Germination in the Genus Leucocoryne (Amaryllidaceae)
}

\author{
Carlos De la Cuadra and Alexis K. Vidal
}

Escuela de Agronomía, Pontificia Universidad Catolica de Valparaíso, Avda. San Francisco s/n, La Palma, casilla 4-D, Quillota, Chile

\section{Susana Lefimil}

Instituto de Biología, Pontificia Universidad Catolica de Valparaíso, Avda. Universidad $N^{\circ} 330$, Placilla sector Curauma, Valparaíso, Chile

\section{Leví Mansur ${ }^{1}$}

Escuela de Agronomía, Pontificia Universidad Catolica de Valparaíso, Avda. San Francisco s/n, La Palma, casilla 4-D, Quillota, Chile

Additional index words. Glory of the Sun, huilli, supraoptimal germination temperature, adaptive strategy

\begin{abstract}
Leucocoryne is a Chilean endemic genus from the Amaryllidaceae family. It is an emerging crop with some registered varieties, currently oriented to a niche ornamental market. In the present work, seed germination in Leucocoryne dimorphopetala, Leucocoryne coquimbensis, Leucocoryne purpurea, Leucocoryne aff. vittata, Leucocoryne aff. violacescens, and Leucocoryne ixioides for seeds stored for 4 months and in $L$. purpurea, Leucocoryne vittata, $L$. aff. vittata, and $L$. ixioides for seeds stored for up to 16 months was analyzed at $10,15,20$, or $25^{\circ} \mathrm{C}$. Germination data were analyzed by the previously developed time-germination model $p=A\left\{1-\exp \left[-k\left(t-t_{0}\right)\right]\right\}$. Each germination curve had a coefficient of determination $\left(R^{2}\right)$ higher than 0.89 , except when there was lack of germination. Results show that higher germination was better achieved at lower $\left(10\right.$ or $\left.15{ }^{\circ} \mathrm{C}\right)$ rather than at the higher temperatures $\left(20\right.$ or $\left.25^{\circ} \mathrm{C}\right)$. When comparing germination results at temperatures of 10 and 15 with results at $20{ }^{\circ} \mathrm{C}$, germination decreased by at least $30 \%$ and became near zero at $25^{\circ} \mathrm{C}$ in seed stored for 4 months. Similarly when seeds were stored for 16 months, germination decreased by $\approx 20 \%$ at $20{ }^{\circ} \mathrm{C}$, and again was near zero for germination at $25{ }^{\circ} \mathrm{C}$. These germination habits of Leucocoryne are interpreted as an adaptive strategy to its natural habitats. In addition, L. dimorphopetala presents a type of dormancy and other species (L. purpurea, $L$. ixioides, and $L$. aff. vittata) may be sensitive to after-ripening changes during storage.
\end{abstract}

The genus Leucocoryne Lindley is endemic to Chile and is one of the 12 genus in the Amaryllidaceae family from South America (Chase et al., 2009; Sassone et al., 2014). Its habitat extends from the northern Atacama desert of Chile, near the city of Iquique (lat. $20^{\circ} \mathrm{S}$ ) (Muñoz, 2000; Zoellner, 1972) to the southern region of the Humid Lake District (lat. $39^{\circ} \mathrm{S}$ ) (Muñoz and Moreira, 2000). Cytologically, it has been divided into two major plant groups with chromosome numbers of $2 n=10(n=5)$ or $2 n=18(n=9)$ (Araneda et al., 2004; Crosa, 1998; Jara-Arancio et al., 2012). This geophyte genus has been shown to have high ornamental value due to its longvase life, various colors and shapes, and its ability to grow in pots or gardens alongside

Received for publication 30 Oct. 2015. Accepted for publication 15 Jan. 2016.

This study was funded by the Fundación para la Innovación Agraria (Proyect PYT-2012-0079), Ministry of Agriculture, Chile and Mansur Agricultural Services Ltda.

${ }^{1}$ Corresponding author. E-mail: levi.mansur@ pucv.cl. and several others in Holland. Bulbs are commercially available in Chile, Japan, Holland, the United States, and others (Olate and Schiappacasse, 2013). The understanding of seed germination, growth, and development is important for breeding purposes and sexual propagation of these species as an ornamental crop (De la Cuadra et al., 2002; De la Cuadra and Mansur, 2004; Kim et al., 1998a, 1998b; Verdugo and Texeira, 2006).

It is known that seed germination over $85 \%$ of $L$. coquimbensis and L. purpurea happens at $10{ }^{\circ} \mathrm{C}$ (De la Cuadra et al., 2002; Jara et al., 2006); for L. coquimbensis, L. purpurea, and L. ixioides germination is near zero at $20{ }^{\circ} \mathrm{C}$ (Schiappacasse et al., 2005); and in L. purpurea, seed germination is totally inhibited at $25{ }^{\circ} \mathrm{C}$ (Jara et al., 2006). Although optimal germination temperature is unknown, the studies above indicate that temperatures at or above $20{ }^{\circ} \mathrm{C}$ inhibit germination and at $10{ }^{\circ} \mathrm{C}$ germination is enhanced. Our work aims to achieve further precision of the effect of temperature on seed germination, in five species and two species affinis originating from Central (lat. $33^{\circ} \mathrm{S}$ ) to the far North of Chile (lat. $20^{\circ} \mathrm{S}$ ).

\section{Materials and Methods}

Seven genotypes were studied including $L$. dimorphopetala, L. coquimbensis, L. purpurea, $L$. vittata, $L$. ixioides, $L$. aff. vittata, and $L$. aff. violacescens (Fig. 1). All these have been described by Araneda et al. (2004) and De la Cuadra et al. (2002). Leucocoryne aff. vittata and $L$. aff. violacescens are still taxonomically unresolved, and have been classified in previous studies as ecotypes Pichicuy and Alcones, respectively (Araneda et al., 2004; De la Cuadra et al., 2002; Mansur et al., 2004).

Seeds of the genotypes studied in the present work were harvested in 2013 (then stored for 4 months) and 2012 (then stored for 16 months) from ex situ bulb collection grown in unheated greenhouse at the School of Agronomy of the Pontificia Universidad Católica de Valparaiso, in Quillota (lat. $32^{\circ} 53^{\prime} \mathrm{S}$; long. $\left.71^{\circ} 12^{\prime} \mathrm{W}\right)$, Chile. Manual cacti with limited irrigation (Bridgen et al., 2002; Catley, 2003; Kim and Ohkawa, 2001; Mansur et al., 2004). There are three commercial varieties currently available in Chile
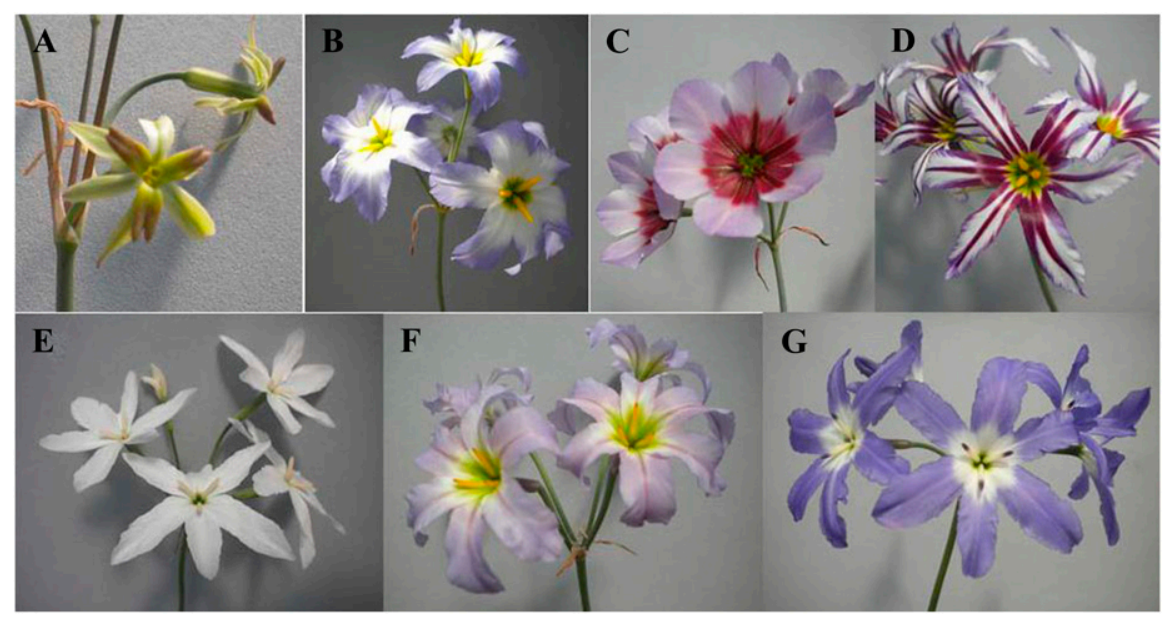

Fig. 1. Leucocoryne genotypes: (A) Leucocoryne dimorphopetala, (B) Leucocoryne coquimbensis, (C) Leucocoryne purpurea, (D) Leucocoryne vittata, (E) Leucocoryne ixioides, (F) Leucocoryne aff. vittata, and (G) Leucocoryne aff. violacescens. 
seed cleaning was performed after harvest and seeds of uniform size from each genotype were obtained for the experiments.

Before sowing, seeds were disinfected with captan (Captan ${ }^{\circledR}$ 50WP; N-trichloromethylthio4-cyclohexene-1,2-dicarboximide; Arysta LifeScience North America, LLC, Cary, NC) at $1 \mathrm{~g} / 100 \mathrm{~mL}$ for $3 \mathrm{~min}$ and rinsed three times with distilled water. Germination was performed on moist paper in petri dishes, under dark conditions at $10,15,20$, or $25 \pm 2{ }^{\circ} \mathrm{C}$. Each replicate consisted of a petri dish containing 50 seeds of a given genotype. A complete randomized design was used with four replicates randomly distributed inside the incubator corresponding to the temperature treatment. Germination evaluation was performed every $2 \mathrm{~d}$. Seeds were considered as germinated when the radicle was $2 \mathrm{~mm}$ or longer. If a genotype did not reach $85 \%$ germination in at least one of the temperature treatments, a tetrazolium test was performed to control seed viability (International Seed Testing Association, 2003).

Two independent experiments were conducted, one with seed stored for 4 months (harvested in 2013) and a second with seeds stored for 16 months (harvested in 2012).

Experiment 1. This was performed on seeds of $L$. dimorphopetala, L. coquimbensis, $L$. purpurea, $L$. aff. vittata, $L$. aff. violacescens, and L. ixioides, stored for 4 months after harvest. Dry storage was performed at room temperature $\left(20 \pm 5^{\circ} \mathrm{C}\right)$ and relative humidity between $50 \%$ and $70 \%$, under dark conditions in paper bags.

Experiment 2. This was performed on seeds of $L$. purpurea, $L$. vittata, $L$. aff. vittata, and $L$. ixioides under the same temperature treatments with seeds stored for 16 months under the same conditions as the previous experiment.

The germination data for each treatment in each experiment were fitted to the model $p=A\left\{1-\exp \left[-k\left(t-t_{0}\right)\right]\right\}$ developed by Mobayen (1980), where $p$ is germination percentage at every determined time $(t), A$ is the final maximum germination achieved, $t_{0}$ is the time to the first germinated seed, and $k$ is a measure of germination time spread. High and low values of $k$ indicate short and long time required from the first to the last seed to germinate, respectively. Median germination rate is determined as $1 / t_{A / 2}$, where $t_{A / 2}$ is the time required to reach median seed germination and is calculated as $t_{0}+0.693 / k$.

A confidence interval for proportions was used for final maximum germination $(A)$ at $P \leq 0.05$. Differences for $t_{0}, k$, and $1 / t_{A / 2}$ were tested by calculating the corresponding regression coefficients confidence intervals (Walpole et al., 2012).

\section{Results}

The seed germination process in Leucocoryne did fit the seed germination model described by Mobayen in 1980 (Fig. 2). Each germination curve had a coefficient of determination $\left(R^{2}\right)$ higher than 0.89 , except when there was lack of germination data at $25{ }^{\circ} \mathrm{C}$ for all genotypes, and at $20{ }^{\circ} \mathrm{C}$ for L. aff. violacescens (Tables 1 and 2).

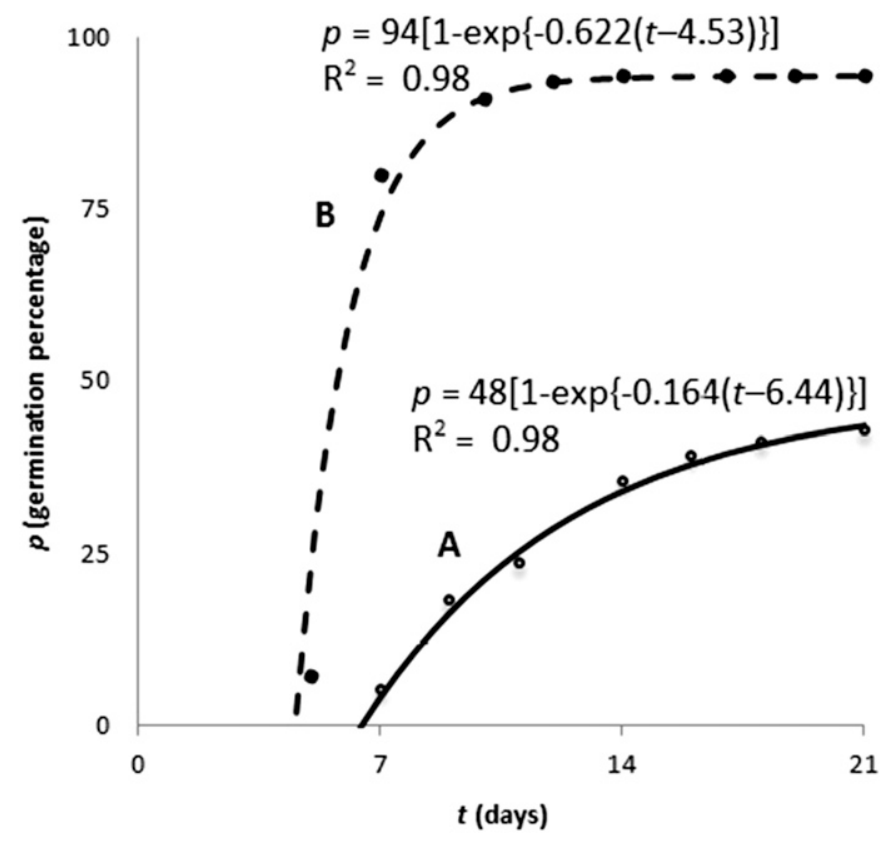

Fig. 2. Example of typical germination curves fitted to Mobayen's model. (A) Seeds of Leucocoryne dimorphopetala stored for 4 months and germinated at $10^{\circ} \mathrm{C}$. (B) Seeds of Leucocoryne vittata stored for 16 months and germinated at $15^{\circ} \mathrm{C}$.

Table 1. Temperature effect on germination of Leucocoryne seeds stored for 4 mo. before sowing, where parameter $A$ is the final maximum germination achieved, $t_{0}$ is the time to the first germinated seed, $k$ is a measure of germination time spread, and $1 / t_{A / 2}$ corresponds to median germination time.

\begin{tabular}{|c|c|c|c|c|c|}
\hline Temperature $\left({ }^{\circ} \mathrm{C}\right)$ & $R^{2}$ & $A(\%)$ & $t_{0}(\mathrm{~d})$ & $k\left(\mathrm{~d}^{-1}\right)$ & $1 / t_{A / 2}\left(\mathrm{~d}^{-1}\right)$ \\
\hline \multicolumn{6}{|c|}{ Leucocoryne dimorphopetala } \\
\hline 10 & 0.98 & $48 \mathrm{a}^{\mathrm{y}}$ & $6.4 \mathrm{a}$ & $0.164 \mathrm{~b}$ & $0.094 \mathrm{a}$ \\
\hline 15 & 0.91 & $53 \mathrm{a}$ & $4.7 \mathrm{a}$ & $0.417 \mathrm{ab}$ & $0.157 \mathrm{a}$ \\
\hline 20 & 0.91 & $12 \mathrm{~b}$ & $3.8 \mathrm{a}$ & $0.361 \mathrm{a}$ & $0.176 \mathrm{a}$ \\
\hline 25 & $\dagger^{z}$ & 0 & & & \\
\hline \multicolumn{6}{|c|}{ Leucocoryne coquimbensis } \\
\hline 10 & 0.95 & $93 \mathrm{a}$ & $8.3 \mathrm{a}$ & $0.319 \mathrm{a}$ & $0.096 \mathrm{a}$ \\
\hline 15 & 0.99 & $92 \mathrm{a}$ & $5.2 \mathrm{a}$ & $0.459 \mathrm{a}$ & $0.149 \mathrm{a}$ \\
\hline 20 & 0.95 & $59 \mathrm{~b}$ & $6.8 \mathrm{a}$ & $0.214 \mathrm{a}$ & $0.099 \mathrm{a}$ \\
\hline 25 & $\dagger$ & 0 & & & \\
\hline \multicolumn{6}{|c|}{ Leucocoryne purpurea } \\
\hline 10 & 0.96 & $85 \mathrm{a}$ & $7.8 \mathrm{a}$ & $0.342 \mathrm{a}$ & $0.102 \mathrm{a}$ \\
\hline 15 & 0.97 & $89 \mathrm{a}$ & $5.2 \mathrm{a}$ & $0.604 \mathrm{a}$ & $0.158 \mathrm{a}$ \\
\hline 20 & 0.99 & $54 \mathrm{~b}$ & $4.2 \mathrm{a}$ & $0.309 \mathrm{a}$ & $0.155 \mathrm{a}$ \\
\hline 25 & $\dagger$ & 1 & & & \\
\hline \multicolumn{6}{|c|}{ Leucocoryne aff. violacescens } \\
\hline 10 & 0.96 & $96 \mathrm{a}$ & $8.7 \mathrm{a}$ & $0.355 \mathrm{a}$ & $0.094 \mathrm{a}$ \\
\hline 15 & 0.93 & $68 \mathrm{~b}$ & $6.0 \mathrm{a}$ & $0.498 \mathrm{a}$ & $0.135 \mathrm{a}$ \\
\hline 20 & $\dagger$ & 0 & & & \\
\hline 25 & $\dagger$ & 0 & & & \\
\hline \multicolumn{6}{|c|}{ Leucocoryne aff. vittata } \\
\hline 10 & 0.96 & $94 \mathrm{a}$ & $8.1 \mathrm{a}$ & $0.518 \mathrm{a}$ & $0.106 \mathrm{a}$ \\
\hline 15 & 0.97 & $95 \mathrm{a}$ & $5.3 \mathrm{a}$ & $0.837 \mathrm{ab}$ & $0.164 \mathrm{a}$ \\
\hline 20 & 0.91 & $30 \mathrm{~b}$ & $7.7 \mathrm{a}$ & $0.205 \mathrm{~b}$ & $0.090 \mathrm{a}$ \\
\hline 25 & $\dagger$ & 0 & & & \\
\hline \multicolumn{6}{|c|}{ Leucocoryne ixioides } \\
\hline 10 & 0.97 & $88 \mathrm{a}$ & $8.6 \mathrm{a}$ & $0.213 \mathrm{ab}$ & $0.084 \mathrm{~b}$ \\
\hline 15 & 0.99 & $58 \mathrm{~b}$ & $5.2 \mathrm{a}$ & $0.225 \mathrm{a}$ & $0.120 \mathrm{a}$ \\
\hline 20 & 0.97 & $17 \mathrm{c}$ & $5.8 \mathrm{a}$ & $0.172 \mathrm{~b}$ & $0.102 \mathrm{ab}$ \\
\hline 25 & $\dagger$ & 2 & & & \\
\hline
\end{tabular}

zMobayen's model, $p=A\left\{1-\exp \left[-k\left(t-t_{0}\right)\right]\right\}$, does not fit due to the lack of germination data.

${ }^{\mathrm{y}}$ Values in the same column of the same genotype, followed by the same letter have no statistically significant difference at $P \leq 0.05$.

When seed was stored for 4 months, the highest germination percentages were achieved at $10^{\circ} \mathrm{C}$ for all species studied. At $15{ }^{\circ} \mathrm{C}$, the results show that $L$. dimorphopetala, $L$. coquimbensis, $L$. purpurea, and $L$. aff. vittata were not significantly different from at $10^{\circ} \mathrm{C}$. However, for $L$. aff. violacescens and
L. ixioides, final maximum germination $(A)$ decreased by $\approx 30 \%$ when compared with germination at $10{ }^{\circ} \mathrm{C}$. When temperature was raised to $20{ }^{\circ} \mathrm{C}, A$ decreased by at least $30 \%$ and inhibited germination almost completely in $L$. aff. violacescens. Finally, germination was nearly zero at $25{ }^{\circ} \mathrm{C}$ for all genotypes 
Table 2. Temperature effect on germination of Leucocoryne seeds stored for 16 mo. before sowing, where parameter $A$ is the final maximum germination achieved, $t_{0}$ is the time to the first germinated seed, $k$ is a measure of germination time spread, and $1 / t_{A / 2}$ corresponds to median germination time.

\begin{tabular}{|c|c|c|c|c|c|}
\hline Temperature $\left({ }^{\circ} \mathrm{C}\right)$ & $R^{2}$ & $A(\%)$ & $t_{0}(\mathrm{~d})$ & $k\left(\mathrm{~d}^{-1}\right)$ & $1 / t_{A / 2}\left(\mathrm{~d}^{-1}\right)$ \\
\hline \multicolumn{6}{|c|}{$\overline{\text { Leucocoryne purpurea }}$} \\
\hline 10 & 0.99 & $92 \mathrm{a}^{\mathrm{y}}$ & $9.2 \mathrm{~b}$ & $0.471 \mathrm{~b}$ & $0.094 \mathrm{~b}$ \\
\hline 15 & 1.00 & $93 \mathrm{a}$ & $4.9 \mathrm{a}$ & $0.659 \mathrm{a}$ & $0.168 \mathrm{a}$ \\
\hline 20 & 0.96 & $72 b$ & $3.2 \mathrm{a}$ & $0.465 \mathrm{~b}$ & $0.214 \mathrm{a}$ \\
\hline 25 & $\grave{\dagger}^{z}$ & 3 & & & \\
\hline \multicolumn{6}{|l|}{ Leucocoryne vittata } \\
\hline 10 & 0.90 & $94 \mathrm{a}$ & $7.5 \mathrm{a}$ & $0.338 \mathrm{ab}$ & $0.105 \mathrm{a}$ \\
\hline 15 & 0.98 & $94 \mathrm{a}$ & $4.5 \mathrm{a}$ & $0.622 \mathrm{a}$ & $0.177 \mathrm{a}$ \\
\hline 20 & 0.98 & $81 \mathrm{~b}$ & $2.9 \mathrm{a}$ & $0.295 \mathrm{~b}$ & $0.191 \mathrm{a}$ \\
\hline 25 & $\dagger$ & 1 & & & \\
\hline \multicolumn{6}{|c|}{ Leucocoryne aff. vittata } \\
\hline 10 & 0.95 & $93 \mathrm{a}$ & $8.3 \mathrm{a}$ & $0.383 \mathrm{a}$ & $0.099 \mathrm{a}$ \\
\hline 15 & 0.96 & $91 \mathrm{a}$ & $4.9 \mathrm{a}$ & $0.683 \mathrm{a}$ & $0.170 \mathrm{a}$ \\
\hline 20 & 0.90 & $62 \mathrm{~b}$ & $4.9 \mathrm{a}$ & $0.211 \mathrm{~b}$ & $0.122 \mathrm{a}$ \\
\hline 25 & $\dagger$ & 1 & & & \\
\hline \multicolumn{6}{|c|}{ Leucocoryne ixioides } \\
\hline 10 & 0.91 & $87 \mathrm{a}$ & $6.7 \mathrm{a}$ & $0.128 b$ & $0.083 \mathrm{a}$ \\
\hline 15 & 0.98 & $81 \mathrm{a}$ & $5.8 \mathrm{a}$ & $0.390 \mathrm{a}$ & $0.131 \mathrm{a}$ \\
\hline 20 & 0.89 & $67 \mathrm{~b}$ & $6.9 \mathrm{a}$ & $0.185 \mathrm{~b}$ & $0.094 \mathrm{a}$ \\
\hline 25 & $\dagger$ & 1 & & & \\
\hline
\end{tabular}

${ }^{z}$ Mobayen's model, $p=A\left\{1-\exp \left[-k\left(t-t_{0}\right)\right]\right\}$, does not fit due to lack of germination data.

${ }^{y}$ Values in the same column of the same genotype, followed by the same letter have no statistically significant difference at $P \leq 0.05$.
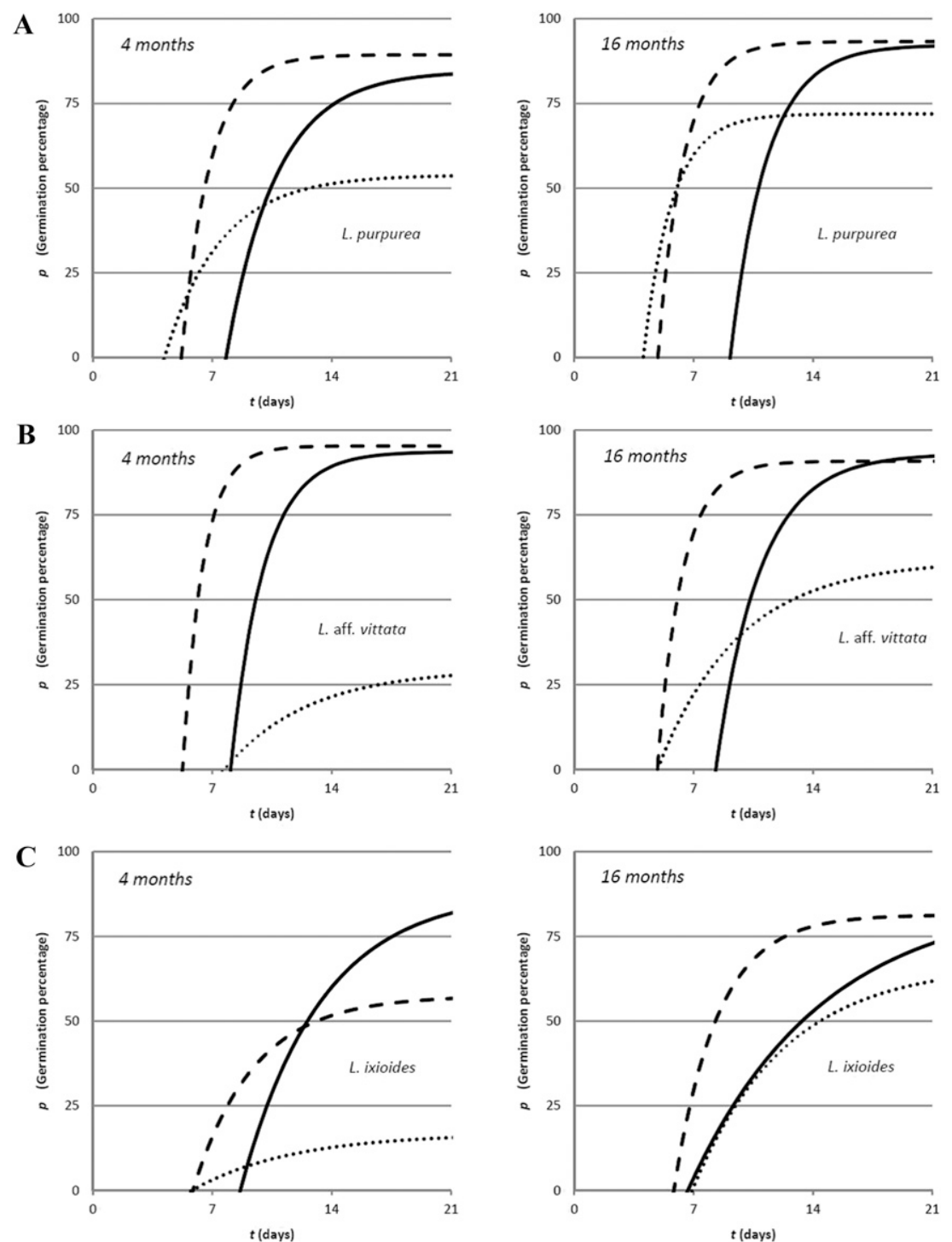

Fig. 3. Effect of temperatures of 10 (solid lines), 15 (dashed lines), and $20{ }^{\circ} \mathrm{C}$ (dotted lines) on seeds of (A) Leucocoryne purpurea, (B) Leucocoryne aff. vittata, and (C) Leucocoryne ixiodes stored for 4 or 16 months.
(Table 1). For seed stored for 16 months, higher germination was observed at lower $\left(10\right.$ or $\left.15{ }^{\circ} \mathrm{C}\right)$ rather than at the higher temperatures $\left(20\right.$ or $\left.25^{\circ} \mathrm{C}\right)$. A similar trend was observed, where increasing temperature to at $20{ }^{\circ} \mathrm{C}$, decreased germination by around $20 \%$ for most genotypes and $13 \%$ in the case of L. vittata (Table 2).

Considering both experiments, the final germination at either 10 or $15{ }^{\circ} \mathrm{C}$ was over $88 \%$. The only exception was $L$. dimorphopetala in Expt 1, where germination reached a maximum of only $53 \%$. A tetrazolium test performed showed a seed viability of $84 \%$ for $L$. dimorphopetala and $91 \%$ for $L$. vittata, which was used as control in the test.

To differentiate the performance of the germination process between 10 and $15{ }^{\circ} \mathrm{C}$, the remaining parameters $t_{0}, k$, and $1 / t_{A / 2}$ were considered. In cases where differences for these parameters were significant, they always show that $15{ }^{\circ} \mathrm{C}$ is a better condition than $10^{\circ} \mathrm{C}$ for seed germination (Tables 1 and 2 ). At $15^{\circ} \mathrm{C}$, the time to the first germinated seed $\left(t_{0}\right)$ was shorter. On the other hand, the measure of germination time spread $(k)$ and median germination rate $\left(1 / t_{A / 2}\right)$ were higher.

\section{Discussion}

Leucocoryne is a geophyte adapted to grow in the desert and Mediterranean climate of Chile being an important component of the Blooming Desert (Jara et al., 2006; Muñoz and Moreira, 2000; Zoellner, 1972). In natural habitat, if rainfall is over $40 \mathrm{~mm}$ (Vidiella and Armesto, 1989), the bulbs sprout from fall to winter, then flower, and set seed at $\approx 100$ to $120 \mathrm{~d}$ from sprouting (Kim et al., 1998a). After the plant reaches maturity, the seeds remain in the soil until next winter and if it rains, they will germinate and form a small bulb (De la Cuadra and Mansur, 2004; Mansur et al., 2004). Based on our field observations and the data presented in this work, we conclude that Leucocoryne seeds in the first year seem to behave as a winter annual, germinating in the winter and senescing in late spring or early summer.

It would be logical to expect that seeds of Leucocoryne have acquired some adaptive strategy as a way to survive in its natural habitat where summers are hot and dry, and winters have mild temperatures with unpredictable rain (Juliá et al., 2008; Novoa and López, 2001). For all species, germination is almost totally inhibited at temperatures of $25{ }^{\circ} \mathrm{C}$. This could be interpreted as an adaptation to their natural habitats, where avoiding germination during hot dry summers would be determinant for the survival of the species (Baskin and Baskin, 2014; Figueroa et al., 2004). If a late spring or summer rain event does occur, it is usually not followed by later similar events that would allow the germinated plantlet to complete its cycle.

Notably in $L$. dimorphopetala germination at 10 or $15{ }^{\circ} \mathrm{C}$ was only $50 \%$, yet the seed was $84 \%$ viable after 4 months of storage at $20 \pm 5{ }^{\circ} \mathrm{C}$, indicating that a type of seed dormancy mechanism is present in this 
species. Leucocoryne dimorphopetala, unlike the other genotypes studied in this work, is characteristic from desert climate and based on molecular data (Jara-Arancio et al., 2014) and flower morphology (L. Mansur, unpublished data) belongs to a different lineage. Under the extreme dryness of the Atacama Desert, inhibition of germination during winters with lack of rain and successive hot summers could be a determinant factor of its survival strategy where its seeds can only germinate when the phenomena of Blooming Desert occurs (Gutiérrez and Meserve, 2003).

When comparing germination of seeds stored for 4 months vs. 16 months, inhibition observed at $20^{\circ} \mathrm{C}$ decreased after the longer storage (Fig. 3). Germination requirements may change during storage at $20 \pm 5{ }^{\circ} \mathrm{C}$, where at supraoptimal temperatures, older seeds (stored for 16 months) have higher germination rate than fresh seeds (stored for 4 months). Leucocoryne seeds may be sensitive to after-ripening changes in dry seed, characterized by widening the temperature range or window permissive for germination (Finch-Savage and Leubner-Metzger, 2006).

This work and that of Jara et al. (2006) shows that L. purpurea, as well as $L$. dimorphopetala, L. coquimbensis, L. purpurea, $L$. vittata, $L$. ixioides, $L$. aff. vitatta, and $L$. aff. violacescens are able to achieve their maximum germination values $(A)$ at $10^{\circ} \mathrm{C}$. For most of the genotypes analyzed, $15^{\circ} \mathrm{C}$ can also be considered optimal. For all of the genotypes, data suggest that $20{ }^{\circ} \mathrm{C}$ and higher are supraoptimal temperatures for germination. When working on laboratory experiments, creating conditions similar to those that the species are adapted to in nature may help achieving optimum growth objectives (Vidal et al., 2012), which in this case are high maximum rate $(A)$, fast $\left(t_{0}\right.$ and $\left.1 / t_{A / 2}\right)$, and uniform germination $(k)$ which in nature occurs from late fall to early spring, when temperatures are around 10 to $15^{\circ} \mathrm{C}$ (Juliá et al., 2008; Novoa and López, 2001).

\section{Literature Cited}

Araneda, L., P. Salas, and L. Mansur. 2004. Chromosome numbers in the Chilean endemic genus Leucocoryne (Huilli). J. Amer. Soc. Hort. Sci. 129:77-80.

Baskin, C.C. and J.M. Baskin. 2014. Seeds: Ecology, biogeography, and evolution of dormancy and germination. 2nd ed. Academic Press, San Diego, CA.

Bridgen, M.P., E. Olate, and F. Schiappacasse. 2002. Flowering geophytes from Chile. Acta Hort. 570:75-80.
Catley, J.L. 2003. Temperature and irradiance effects on flowering of two species of Leucocoryne. J. Amer. Soc. Hort. Sci. 128:809814

Chase, M.W., J.L. Reveal, and M.F. Fay. 2009. A subfamilial classification for the expanded asparagalean families Amaryllidaceae, Asparagaceae and Xanthorrhoeaceae. Bot. J. Linn. Soc. 161:132-136.

Crosa, O. 1998. Los cromosomas de nueve especies del género chileno Leucocoryne Lindley, (Alliae-Alliacea). Bol. Invest. Fac. Agrom. Univ. de la República Uruguay 17:1-12.

De la Cuadra, C. and L. Mansur. 2004. Descripción de la primera etapa del ciclo de vida de tres genotipos de Leucocoryne sp.: Semilla a bulbo. Agricultura Técnica 64:205-212.

De la Cuadra, C., L. Mansur, G. Verdugo, and L. Arriagada. 2002. Deterioro de las semillas de Leucocoryne spp. en función del tiempo de almacenaje. Agricultura Técnica 62:46-55.

Figueroa, J.A., P. León-Lobos, L.A. Cavieres, H.W. Pritchard, and M. Way. 2004. Ecofisiología de semillas en ambientes contrastantes de Chile: Un gradiente desde ecosistemas desérticos a templado-húmedos, p. 81-98. In: M. Cabrera (ed.). Fisiología Ecológica y Evolutiva de Plantas: Mecanismos y Respuestas a Estrés en los Ecosistemas. Ediciones Universidad de Valparaíso, Valparaíso, Chile.

Finch-Savage, W.E. and G. Leubner-Metzger. 2006. Seed dormancy and the control of germination. New Phytol. 171:501-523.

Gutiérrez, J.R. and P.L. Meserve. 2003. El Niño effects on soil seed bank dynamics in northcentral Chile. Oecologia 134:511-517.

International Seed Testing Association. 2003 ISTA working sheets on tetrazolium testing. Vol. I. ISTA, Bassersdorf, Switzerland.

Jara, P.A., G. Arancio, R. Moreno, and M.R. Carmona. 2006. Factores abióticos que influencian la germinación de seis especies herbáceas de la zona árida de Chile. Rev. Chil. Hist. Nat. 79:309-319.

Jara-Arancio, P., M.T.K. Arroyo, P.C. Guerrero, L.F. Hinojosa, G. Arancio, and M.A. Méndez. 2014. Phylogenetic perspectives on biome shifts in Leucocoryne (Alliaceae) in relation to climatic niche evolution in western South America. J. Biogeogr. 41:328-338.

Jara-Arancio, P., P. Jara-Seguel, C. Palma-Rojas, G. Arancio, and R. Moreno. 2012. Karyological study in fifteen Leucocoryne taxa (Alliaceae). Biologia 67:289-295.

Juliá, C., S. Montecinos, and A. Maldonado. 2008. Características Climáticas de la Región de Atacama, p. 25-42. In: F.A. Squeo, G. Arancio, and J.R. Gutiérrez (eds.). Libro Rojo de la Flora Nativa y de los Sitios Prioritarios para su Conservación: Región de Atacama. Ediciones Universidad de La Serena, La Serena, Chile.

Kim, H.H. and K. Ohkawa. 2001. Introduction of two Chilean geophytes, Leucocoryne coquimbensis F. Phil. and Zephyra elegans D. Don as new ornamentals. Acta Hort. 552:179-183.

Kim, H.H., K. Ohkawa, and E. Nitta. 1998a Effects of bulbs weight on the growth and flowering of Leucocoryne coquimbensis F. Phil. Acta Hort. 454:341-346.

Kim, H.H., K. Ohkawa, and E. Nitta. 1998b. Fall flowering of Leucocoryne coquimbensis F. Phil. after long-term bulb storage treatments. HortScience 33:18-20.

Mansur, L., O. Zoellner, P. Riedemann, G. Verdugo, and C. Harrison. 2004. Leucocoryne, a native Chilean genus and it use as a garden plant. Pontificia Universidad Católica de Valparaíso, Valparaíso, Chile.

Mobayen, R.G. 1980. Germination and emergence of citrus and tomato seeds in relation to temperature. J. Hort. Sci. 55:291-297.

Muñoz, M. 2000. Consideraciones sobre los géneros endémicos de monocotiledóneas de Chile. Noticiario Mensual Museo Nacional de Historia Natural, Santiago, Chile 343: $16-27$.

Muñoz, M. and A. Moreira. 2000. Géneros endémicos de monocotiledóneas de Chile. Chloris chilensis. 18 Aug. 2015. <http://www.chlorischile. $\mathrm{cl} /$ Monocotiledoneas/leucocoryne.htm>.

Novoa, J.E. and D. López. 2001. IV Región: El Escenario Geográfico Físico, p. 13-28. In: F.A. Squeo, G. Arancio, and J.R. Gutiérrez (eds.). Libro Rojo de la Flora Nativa y de los Sitios Prioritarios para su Conservación: Región de Coquimbo. Ediciones Universidad de La Serena, La Serena, Chile.

Olate, E. and F. Schiappacasse. 2013. Geophyte research and production in Chile, p. 449-469. In: R. Kamenetsky and H. Okubo (eds.). Ornamental geophytes: From basic science to sustainable production. Taylor \& Francis Group, FL.

Sassone, A.B., S.C. Arroyo-Leuenberger, and L.M. Giussani. 2014. New circumscription of the tribe Leucocoryneae (Amaryllidaceae, Allioideae). Darwiniana, nueva serie 2(2): 197-206.

Schiappacasse, F., P. Peñailillo, P. Yañez, and M. Bridgen. 2005. Propagation studies on Chilean geophytes. Acta Hort. 673:121-126.

Verdugo, G. and J. Texeira. 2006. From wild to the table: Leucocoryne and chloraea, p. 356-359. In: J. Teixeira (ed.). Floriculture, ornamental and plant biotechnology: Advances and topical issues Vol IV. Global Science Books, London, UK.

Vidal, A.K., D.S. Han, M. Nakano, and Y. Niimi. 2012. Decreased time from seed to flowering corm size in Zephyra elegans via in vitro cultivation. Cien. Inv. Agr. 39:577-584.

Vidiella, P.E. and J.J. Armesto. 1989. Emergence of ephemeral plant species from soil samples of the Chilean coastal desert in response to experimental irrigation. Rev. Chil. Hist. Nat. 62:99-107.

Walpole, R.E., R.H. Myers, S.L. Myers, and K. Ye. 2012. Probability and statistics for engineers and scientists. 9th ed. Prentice Hall, Boston, MA.

Zoellner, O. 1972. El género Leucocoryne. Anales Museo Historia Natural, Valparaíso, Chile 5:9-83. 